\title{
REALIDAD Y REALISMO EN EL TEATRO
}

\author{
Santiago TRANCÓN \\ Instituto Calderón de la Barca (Madrid) \\ ramir@inicia.es
}

Resumen: Se definen tres niveles de realidad (real, transreal e imaginario), en función de la consistencia y diversidad ontológica que nuestra cultura otorga al concepto de «realidad». Se aplica este esquema al análisis del teatro como fenómeno artístico en el que la realidad y la ficción establecen una relación particular y diferencial (mímesis o representación).

Résumé: Il y a trois niveaux ou formes à construire la réalité (réel, transréel et imaginaire) que notre culture établie d'accord au diversité ontologique du réel. On aplique cette analise au thêatre à partir de son particularité artistique: l'union entre réalité et fiction qu'on apelle mimesis ou représentation.

Palabras clave: Realidad. Ficción. Transreal. Imaginario. Mímesis.

Mots clé: Réalité. Fiction. Transréel. Imaginaire. Mimésis.

El teatro es un hecho artístico cuyo rasgo esencial (y diferencial) es la particular relación que establece entre realidad y ficción. En el teatro la ficción se hace realidad y la realidad se transmuta en ficción. Ficción real y realidad 
ficticia: el teatro, por su misma naturaleza, nos obliga a reflexionar sobre el sentido de la realidad y realismo en el arte.

Comencemos presentando un esquema global que permita dar fundamento y coherencia a nuestras conjeturas. Se trata de una síntesis de carácter descriptivo acerca de nuestro modo de concebir la realidad en sus diversos niveles. Partimos de dos afirmaciones de evidencia común: que el teatro es, por un lado, un hecho real, o sea, que tiene una existencia física y social concreta manifestada en instituciones, obras, prácticas y textos considerados literarios o teatrales; por otro lado, que el teatro es representación, es decir, que tiene un carácter mimético, lo que implica tomar como referente algún tipo de realidad a la que se representa.

Empecemos por presentar un diagrama (página siguiente).

Expliquemos este esquema. Las siglas mayúsculas nodales significan lo siguiente:

$R T:$ Realidad Total

$R O$ : Realidad Objetiva

$R T R$ : Realidad Transreal

$R I$ : Realidad Imaginaria.

Como puede verse, se trata de tres grandes conjuntos incluidos en otro mayor, al que llamamos Realidad Total $(R T)$. A la realidad total y, por tanto, a las tres modalidades de realidad que incluimos en ella, hemos de aplicar un principio general: toda percepción de la realidad es una interpretación. Nuestra relación con el mundo siempre está mediatizada por la construcción e interpretación que hacemos de la realidad. Como dice Jacques Ancet, «nunca nos relacionamos con las cosas tal y como ellas son, sino tal y como las construimos» (1999: 89). Por tanto, no existe una realidad única y uniforme, previa y externa, ya que la realidad como tal es una construcción cognitiva hecha a partir del lenguaje y la cultura. Este hecho es el que da sentido a nuestro esquema, ya que trata de explicar cómo construimos esa realidad y el grado de consistencia y fiabilidad que otorgamos a cada nivel de realidad constituido ${ }^{1}$.

\footnotetext{
${ }^{1}$ Conviene hacer una aclaración general respecto al término «realidad». Como dice J. F. Lyotard «el término 'realidad' no implica en absoluto una remisión a una sustancia material. Podría definírselo mejor por la pre-existencia» (1989: 76). Precisamente porque la realidad no es algo dado como tal, sino construido por la conciencia, tiene sentido el diagrama que proponemos de diversos niveles de realidad. Sobre el fondo de una «pre-existencia» indiferenciada, la conciencia (que siempre es conciencia de $\mathrm{y}$, por tanto, es inseparable del mundo) construye la realidad y le otorga distintos grados de «consistencia» $\mathrm{o}$ «independencia» respecto a sí misma.
} 


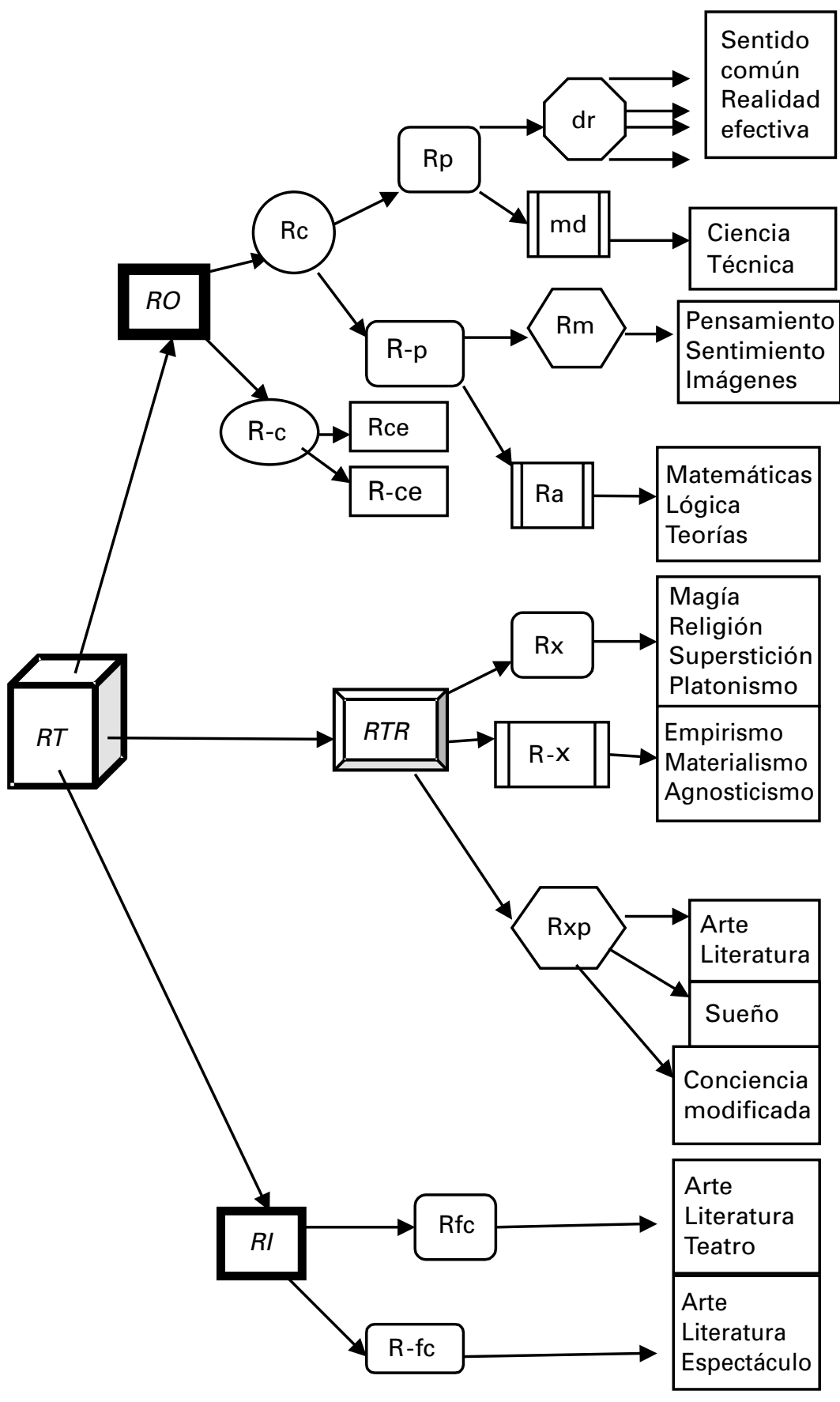


Cada uno de estos tres tipos de realidad puede considerarse configurador o creador de un mundo propio. Así, podemos decir que la totalidad de las $R O$ conforma o compone el mundo real $(M R)$ que cada cultura conoce y construye.

La totalidad de las $R T R$, por su lado, está formada por realidades consideradas o tenidas para algunos, según los casos, como existentes $(\mathrm{Rx})$, inexistentes (R-x), o experimentables ( $\mathrm{Rxp})$. Cada una de estas $R T R$ puede configurar también mundos propios, mundos transreales (MTR), aunque, en general, presentan menos consistencia que el $M R$; están, de hecho, menos configurados o estructurados, ya que su referente no es perceptible ni conocido directamente o, si lo es de algún modo, es menos «socializable», menos intersubjetivo y más individual, dependiendo mucho, al mismo tiempo, del grupo en el que cada una de estas formas de cognición transreal se realice.

Por último, la totalidad de las $R I$ puede configurar mundos imaginarios $(M I)$, en los que se incluyan mundos imaginarios concretos construidos con realidades ficticias $(\mathrm{Rfc})$ o no ficticias $(\mathrm{R}-\mathrm{fc})$.

La mayor complejidad, como puede observarse en el diagrama, se encuentra en los mundos objetivos, reales o $M R$. Distinguimos aquí la realidad conocida (Rc) y la realidad desconocida o no conocida (R-c). Dentro de la realidad no conocida diferenciamos la realidad conocible (Rce) de la realidad no conocible (R-ce). Por Rce entendemos todas aquellas realidades que hoy no conocemos, pero que podemos llegar a conocer porque están al alcance de las posibilidades humanas. Las R-ce son, en cambio, realidades que están fuera del alcance humano, aquello que el hombre nunca podrá llegar a conocer. Por supuesto que esta realidad no conocible para algunos no es tal, porque consideran que tarde o temprano la ciencia acabará conociéndola. El comprobar cómo muchas de las realidades que hoy conocemos fueron consideradas en otro tiempo inconocibles (e irrealizables), parece apoyar a quienes así piensan. La ciencia y la tecnología modernas alimentan la ilusión de que todo, o casi todo, puede llegar a ser conocido y manipulado por el hombre, pero esto no deja de ser más que una fantasía. Los límites del conocimiento humano no podemos establecerlos de antemano, pero sabemos que nuestro saber es limitado, incluso muy limitado, si lo comparamos con la vastedad del universo, por más que nuestros descubrimientos y nuestro poder tecnológico lleguen a ser verdaderamente asombrosos y fascinantes.

Las Rc (realidades conocidas) son de dos tipos: realidades perceptibles (Rp) y realidades no perceptibles (R-p). Otorgamos aquí a la percepción un valor sensorial, incluyendo a todo lo que es visible, audible y palpable (me- 
diante el tacto, pero también el gusto, el olfato o el sentido «cenestésico»o corporal). Esta percepción puede ser directa (dr) —o sea, llevada a cabo a través de los sentidos corporales - o mediada o mediatizada (md), es decir, realizada mediante procedimientos tecnológicos e instrumentos técnicos (microscopio electrónico, microscopio de túnel, telescopio, radar, rayos X, láser, receptores de ondas, satélites, robots, etc.), que amplían los límites sensoriales humanos. El conjunto de las realidades perceptibles $(\mathrm{Rp})$ configura el mundo del sentido común o la realidad efectiva, a la que otorgamos el mayor grado de objetividad o existencia ontológica. La otra realidad a la que llamamos realidad no perceptible (R-p), es una realidad objetiva $(R O)$, pero no la situamos al mismo nivel de objetividad real y sensible que la realidad perceptible. Marca la entrada del sujeto en la percepción, o el observador en lo observado, aunque sabemos que la percepción sensorial también está predeterminada por las condiciones del sujeto, y que el mundo percibido como $R O$ es ya un mundo configurado y construido por el sujeto. Dentro de esta R-p o realidad no perceptible a través de los sentidos, hemos incluido los pensamientos, sentimientos e imágenes mentales, o sea, la realidad interna o subjetiva. Esta realidad, como tal, la consideramos $R O$ o «realidad de verdad», ya que la incluimos en el primer nivel de realidad que estamos distinguiendo dentro de ese gran conjunto al que llamamos Realidad Total. No entramos a discutir el problema del referente, o sea, si el contenido de esos pensamientos, sentimientos o imágenes tiene un referente no sólo subjetivo, sino exterior, ya que este problema no depende de la actividad mental como tal, sino de la relación entre esta actividad y el mundo exterior. Como tales, los pensamientos, sentimientos e imágenes mentales son realidades objetivas, en el sentido de que son hechos efectivos del sujeto, que suceden de verdad. Pero al no poderse objetivar en cuanto tales, ni ser observados directamente por los sentidos, sino a través de sus manifestaciones lingüísticas, corporales u orgánicas ${ }^{2}$, marcan, dentro del mundo real o efectivo, un nivel claramente diferenciado del de las realidades sensibles o sensoriales.

La otra flecha de nuestro diagrama señala las realidades no perceptibles de naturaleza científica, como las que se configuran mediante la actividad matemática, la lógica o las teorías científicas. Estas realidades son mentales o cognitivas, como las que conforman el mundo subjetivo anteriormente señalado, pero se diferencian por su separación del sujeto, en la medida en que apuntan necesariamente hacia referentes externos o el mundo real efectivo en

${ }^{2}$ Para el mecanicismo materialista y el conductismo radical sí son observables, ya que identifican actividad neurológica con pensamiento o actividad mental, no reconociendo esta actividad como una realidad de nivel ontológico o emergente distinto (la conciencia). 
el que esas realidades mentales se concretan o confirman. Son realidades objetivadas y abstractas, y como tales las construye el sujeto, al contrario de las realidades subjetivas, que pueden mantenerse por completo encerradas en la interioridad del sujeto, aunque también se puedan exteriorizar y transmitir intersubjetivamente. A las realidades científicas de carácter abstracto las diferenciamos de las realidades percibidas a través de medios tecnológicos, porque éstas tienen un carácter más concreto y directamente observable o perceptible.

Tenemos, por tanto, un mundo real configurado o construido con $R O$ de distinto nivel, pero al que otorgamos, en general, un valor de realidad efectiva o realidad de verdad. Este $M R$ o mundo real es fundamental en la discusión que nos ocupa, o sea, la de determinar las relaciones entre teatro y realidad y, por tanto, en qué sentido hablamos de realismo en el teatro. Si no aclaramos a qué mundo pertenece el referente de los signos empleados en el teatro (verbales o no verbales), nos resultará difícil resolver el nivel de realidad mimética, pragmática, deíctica y ostensible que cada signo o proposición puede encerrar, o sea, qué complejas relaciones establecen los signos teatrales entre realidad y ficción.

Pero no limitamos la realidad a este $M R$ o mundo verdaderamente real. También hemos de tomar en consideración realidades que configuran otros mundos, o sea, los mundos transreal e imaginario. Llamamos realidad transreal a la que, sin hacer ahora distinciones más precisas por innecesarias, podríamos llamar igualmente «suprarreal», «ultrarreal», o incluso «sobrenatural», «metafísica», «transmental», «transracional» 0 «trascendente». Es la realidad oculta de todas las teorías esotéricas, místicas, alquímicas y cabalísticas; la realidad aparte de los chamanes y brujos de las culturas animistas y «primitivas»; el mundo mítico, sagrado y temido de los dioses, héroes y demonios de todas las religiones; el mundo desconocido del más allá (más allá de la muerte y más allá del mundo percibido); el mundo deseado y temido de todas las supersticiones, etc. Pero también el mundo platónico de las ideas absolutas y el de todos los idealismos metafísicos que siguieron, la realidad inconsciente y latente del psicoanálisis y los arquetipos, la realidad evanescente de los sueños o la realidad experimentada y sentida en estados no ordinarios de conciencia. Nos encontramos ante un nivel de realidad que no puede ser corroborado del mismo modo que puede ser confirmado el $M R$ del primer nivel, ya que depende sobre todo de la actitud y la experiencia del sujeto el otorgarle un grado mayor o menor de realidad. El empirismo, el racionalismo mecanicista o materialista, así como todo tipo de agnosticismos, consideran esta transrealidad como irrealidad, ilusión, engaño, fantasmagoría, superstición e ignorancia, o sea, como un mundo inexistente, meramente 
creado por la imaginación o la mente humana. El argumento básico es que esa realidad no puede ser percibida por los sentidos ni demostrada por medios racionales o científicos y, por tanto, afirmar su existencia no es más que una muestra de irracionalidad. Asimilan esta $R T R$ a la $R I$ o realidad puramente imaginaria. Si algo de esta realidad tiene interés o valor real, piensan, ya lo descubrirá la ciencia, librándonos, como ha ocurrido a lo largo de la historia, de la irracionalidad, la superstición y la ignorancia propias del pensamiento primitivo. Este racionalismo radical tiene hoy, sin embargo, poca base científica. La ciencia reconoce gran cantidad de fenómenos sobre los que no puede establecer ninguna explicación. Pero, ante la dificultad de establecer límites precisos entre realidad y fantasía, la mayoría está inclinada a rechazar como irracional cualquier supuesto de «realidad no real», sea sobrenatural o simplemente desconocida. No es sólo el miedo a lo desconocido, sino el miedo a que el mundo familiar y conocido se tambalee y deje de ser un mundo completo, estable y seguro, corroborado por nuestros sentidos o por la ciencia, cuyo prestigio se fundamenta, sobre todo, en los logros tecnológicos que todos podemos comprobar cada día en nuestra realidad más inmediata. Sin embargo, la presencia de lo transreal bajo múltiples formas y creencias, en gran parte inconscientes, es un hecho absolutamente incuestionable, por lo que no basta con negarla para que deje de importarnos, inquietarnos y despertar los más inesperados anhelos y temores. Y esto sucede, no porque la consideremos una realidad meramente imaginaria, sino porque le otorgamos un nivel de realidad distinto al de la simple fantasía o imaginación.

La $R T R$ tiene mucho que ver con el arte y la literatura, no sólo en su origen, sino en la forma y el contenido de muchas de sus obras. Bastaría recordar la importancia que el surrealismo otorgó a los sueños, el inconsciente y los estados no ordinarios de conciencia. De todo esto se ha nutrido, a partir de las vanguardias, el arte, la literatura y el teatro moderno. Lo que llamamos estados modificados o no ordinarios de conciencia ${ }^{3}$ tiene especial relevancia en el arte y el teatro actual en dos sentidos: 1) como tema frecuente de las obras, presentado casi siempre a partir de personajes «anormales», problemáticos, enfermos, locos, utópicos, etc.; 2) como método de «inspiración» o fuente de escritura e invención. Toda la literatura moderna está atravesada por personajes «extraños» y experiencias no ordinarias de conciencia. Es sintomática la exaltación y elogio de la locura (desde Cervantes a Artaud) o de la irracionalidad y los sueños (surrealismo); la transmisión y descripción de experiencias más o

${ }^{3}$ Preferimos no utilizar la expresión «estados alterados de conciencia», muy usada en antropología, por considerar que lleva implícito un sesgo negativo que ayuda muy poco a comprender los fenómenos a los que nos estamos refiriendo. 
menos alucinatorias (desde el simbolismo hasta hoy); la búsqueda de trances y vivencias de «otra realidad» (Grotowski y las vanguardias, por ejemplo), etc. La antropología, acercándonos a la comprensión y aceptación de otras culturas, puso en crisis el etnocentrismo occidental y ayudó en gran medida a la revalorización de todo este mundo relacionado con la $R T R$, parte innegable de la realidad total sobre la que se asienta nuestra cultura, independientemente del nivel de realidad o consistencia que otorguemos al mundo en el que esa transrealidad se manifiesta. En el teatro nos encontramos frecuentemente con la presencia de esta otra realidad, a la que nos vemos obligados a nombrar de muchos modos. La ciencia también ha contribuido a otorgar sentido a esta realidad oculta o invisible, pero experimentada o sentida, sobre la que con frecuencia no podemos afirmar ni negar su existencia real, ya que unas veces se nos impone con absoluta certeza y otras nos confunde y sume en la incredulidad, y que tanto se nos presenta mediante ilusiones vaporosas como a través de evidencias probadas de imposible negación. Francisco Gutiérrez Carbajo, por ejemplo, analizando el teatro de Alfonso Vallejo, se ve necesitado de hablar de «realidad aparencial, metarrealidad y subrealidad» para referirse a esa otra realidad tan presente en las obras de este autor. Como bien dice:

La realidad nunca muestra una sola cara, y aunque en un primer punto de vista así lo parezca, la cara que se muestra está a la vez implicando y explicando la contraria. [...] La realidad es tremendamente poliédrica, y el denominado realismo te muestra solamente la superficie. Te explica, pero no te implica (2001: 19).

Que la realidad es poliédrica significa que es algo más, y algo más complejo, que lo que el sentido común define como realidad ordinaria o realidad real. Un realismo limitado a la representación de esta realidad es limitativo, tiene poco interés en el teatro. Por el contrario, una concepción del mundo basada en «la multiplicidad de lo real», abre las puertas del teatro a mundos artísticos de mucha mayor significación y profundidad, tal y como nos revela el teatro de Alfonso Vallejo: «No es que quiera escamotear la realidad: es que sabe que ésta es plural y poliédrica, que los personajes que la pueblan son igualmente diversos y que sólo podemos descubrir una multiplicidad de voces y una pluralidad de gestos» (Gutiérrez Carbajo, 2001: 56).

Para una mejor comprensión de esta experiencia de lo transreal, y su relación el tercer nivel de realidad, la $R I$ o realidad imaginaria, conviene aclarar mejor su origen, que no es otro que el de la propia percepción humana y su naturaleza predeterminada y construida. Ya hemos dicho que no nos relacionamos con la realidad misma, sino con imágenes y representaciones 
construidas y aprendidas a través del lenguaje. Al darnos cuenta del carácter intersubjetivo y predeterminado de nuestra percepción, somos conscientes de que algo de la realidad se escapa, de que hay algo ahí que no podemos encerrar en imágenes y palabras. Este sentimiento de que hay algo en la realidad que se nos escapa, que se resiste a nuestra aprehensión y comprensión, pero que podemos llegar a «sentir» 0 «presentir», es el origen de todo tipo de reacciones, desde el realismo empirista a las creencias más irracionales e imperiosas, de las experiencias místicas o poéticas a la incredulidad más radical y el rechazo de todo tipo de ilusión subjetiva. El arte encuentra una solución satisfactoria (relativamente satisfactoria) al dar salida a la atracción, perplejidad e incertidumbre que la conciencia de esa otra realidad nos produce. Si la realidad es algo más y puedo sentir ese algo más, no sólo imaginarlo, la realidad transreal es fuente de una experiencia estética no ordinaria que produce un placer nuevo: el sentimiento de lo real. La creencia en esa transrealidad puede significar, no una huida, sino una sed de realidad, de contacto más real y directo con la realidad del mundo, que se nos escapa:

Algo que me saca de mi rutina mental -me conmueve, en el sentido primario del término. ¿La realidad? No. Acabo de tener-por mínima que sea-la experiencia de lo que yo llamaría lo real. Distinción que me parece esencial si se quiere evitar caer en una doble confusión: la del realismo que pretende darnos el mundo «tal y como es», mientras que lo único que nos propone de él es una imagen —una formalización codificada (que yo llamaría «realidad»_-; la del formalismo que, denunciando el componente verbal de toda realidad y, por tanto, la ilusión realista, ya no ve la literatura y la poesía sino como un trabajo de y sobre el lenguaje sin otro fin que él mismo. Si, por tanto, la realidad es esta descripción del mundo que habita cada hombre desde su nacimiento por intermedio de la lengua que habla, lo real será lo que la desborda: la irrupción de lo insólito en el curso bien regulado de la existencia. Un insólito muy particular, sin embargo, pues en lugar de hacerme escapar del mundo que me rodea, me hace verlo súbitamente como por primera vez. Clément Rosset muestra que un violento desconcierto, un fallecimiento, una ruptura amorosa, puede poner a quien lo sufre frente a lo que ya estaba allí aunque él no lo veía: lo cotidiano más banal vuelto bruscamente presente en su básica in-significancia. Experiencia de des-condicionamiento a la cual, de manera menos dolorosa, más exaltante, pueden conducir el arte, la literatura y, en particular, la poesía (Ancet, 1999: 91) ${ }^{4}$.

${ }^{4} \mathrm{H}$. Bergson relaciona el arte con esa búsqueda de «lo real»: «El arte no es seguramente más que una visión más directa de la realidad» (1986: 129). Y más en concreto, respecto al teatro: «Lo que el drama va buscando y consigue poner a plena luz es una realidad profunda que las necesidades de la vida nos ocultan» (Ibid: 130). 
Al hablar de esta experiencia de transrealidad estamos abriendo la puerta a una explicación de lo que se ha llamado transcotidianidad, desautomatización y transracionalidad, considerados recursos y efectos del lenguaje literario o poético a partir del formalismo ruso. Resumiendo, diríamos que al arte le interesa no tanto la realidad real, sino lo real, entendido como experiencia o contacto directo con eso que el lenguaje ordinario y la percepción habitual, por su propia naturaleza y finalidad, niegan o hacen imposible. Cómo construir un paso entre esas dos percepciones será la materia propia del arte, ahí donde el artista debe trabajar de modo específico.

Nos queda por aclarar el tercer nivel de realidad al que hemos denominado realidad imaginaria $(R I)$, tan estrechamente vinculado a la literatura, el arte y el teatro. A diferencia de los dos niveles anteriores, la imaginación produce realidades que no necesitan ser referidas a una realidad exterior o separada del sujeto. La realidad imaginaria existe sólo como construcción mental, independientemente de su contenido referencial. Es, por tanto, siempre subjetiva. Sin embargo, podemos objetivar esa realidad mental o imaginaria a través del lenguaje y/o mediante un proceso de objetualización, materialización o representación material. Así, un cuento es la traslación o construcción de una realidad imaginaria a través de la palabra, lo mismo que puede serlo un poema o una escena teatral. También podemos objetivar una realidad imaginaria mediante un cuadro, una partitura o una película. Lo que nos interesa destacar ahora es el origen mental e imaginario de estas realidades. El que la imaginación opere sobre datos y experiencias reales vividas por el sujeto no cambia la naturaleza de esta realidad imaginaria. La denominamos imaginaria en sentido amplio, ya que no la limitamos a las representaciones icónicas y visuales, sino a cualquier representación mental de naturaleza sensible (sonora, táctil, olfativa, cenestésica, etc.). Podemos hablar, en este sentido, incluso de pensamientos imaginarios. Lo importante es la conciencia que el sujeto tiene - $\mathrm{y}$ los receptores de las producciones imaginarias también- de la naturaleza subjetiva y mental de esta realidad inventada y construida; o sea, que no pretende validarse ni verificarse por su relación con la realidad real, sino que se constituye con independencia de la realidad objetiva. Podríamos decir que es una realidad en sí misma autorreferente o autosuficiente.

La $R I$ tiene dos modalidades: la ficticia (Rfc) y la no ficticia (R-fc). La realidad imaginaria ficticia añade un elemento al carácter imaginario de esta realidad: el presentarse de modo consciente e intencional como no real, como realidad separada de la realidad real por una convención y una decisión del sujeto productor o creador de esa realidad imaginaria. La ficción no es 
ficción si no se acepta como tal ${ }^{5}$. Esto implica un modo de construir y transmitir esa realidad imaginaria distinta de la realidad imaginaria no ficticia. En este caso, aun sabiendo que la realidad es imaginaria, no se nos presenta como separada totalmente de la realidad real, ya que se vincula a la experiencia del sujeto. Así, un poema es una realidad imaginaria, pero el sujeto no la construye para que la vivamos como ficción, sino simplemente como realidad imaginaria. Digamos que la realidad imaginaria no ficticia no marca una separación intencional con el mundo de las otras realidades (la $R O$ y la $R T R$ ), sino que deja un espacio de conexión real con estos otros mundos reales para que el sujeto los transite o rellene con su vivencia personal. No deja de ser una realidad imaginaria, pues no pretende hacerse pasar por real efectiva, ni siquiera por transreal; no finge ser otra cosa, pero, al mismo tiempo, se proyecta sobre algo que no es ficticio, en el sentido de que puede ser vivido y experimentado realmente por el sujeto, como es el caso de la poesía 6 .

La realidad ficticia puede construir diversos tipos de mundos, mundos posibles o mundos imposibles desde el punto de vista de la realidad real (mundos reales), o mundos verosímiles o inverosímiles desde el punto de vista de su coherencia o consistencia interna (mundos imaginarios). Establecemos aquí una relación entre ficción y realidad, pero no para anular el carácter imaginario de la $R I$, sino porque toda $R I$ tiene necesariamente un contenido real que, de modo inevitable, por ser constitutivo de su propio carácter imaginario, ponemos en relación con mundos reales $(M R$ o $M T R)$. Una realidad es imaginaria por no ser real en el mismo sentido que lo son las realidades efectivas del mundo primero o mundo real, ya que este nivel de realidad distinto se define precisamente por oposición al $M R$.

Existen dos polos dentro de esta referencia al mundo real que la ficción necesariamente encierra: el polo realista y el polo fantástico. El realista acentúa la semejanza o proximidad de la ficción con el mundo real; el polo fantástico se separa de las leyes y contenidos de ese mundo real. Los mundos ficticios realistas se construyen de acuerdo con su posibilidad de existencia en el mundo real; los mundos ficticios fantásticos marcan la imposibilidad de existencia en el mundo real conocido. Sin embargo, tanto los mundos ficticios realistas como los fantásticos nunca dejan de ser imagina-

${ }^{5}$ Dejamos aquí de lado el modo cómo se presenta en la vida cotidiana la ficción y la no ficción, pues está claro que la ficción encubierta se puede convertir en engaño, mentira o error.

${ }^{6}$ Una consecuencia de todo ello es afirmar el carácter no mimético de la poesía, ya que el poema no trata de imitar ninguna realidad, sino, en todo caso, imitar una vivencia, o, mejor, inducirla mediante la palabra. 
rios y ficticios, por lo que nunca serán copias o reproducciones del mundo real, con independencia de que unos u otros pongan en cuestión la solidez o los fundamentos del mundo real, como ocurre especialmente en la literatura fantástica.

Digamos, para acabar la explicación de nuestro diagrama, que estos tres mundos, mundo 1 o $M R$, mundo 2 o MTR, y mundo 3 o MI, conforman el mundo total o $M T$, pero mantienen estrechas relaciones entre sí, dependiendo de los sujetos y las culturas el modo particular de relación que establezcan. La separación, salvo en sujetos muy racionalistas o rígidos, nunca es total. La evolución histórica, por otro lado, está constantemente produciendo cambios y reajustes, borrando fronteras y redefiniéndolas ${ }^{7}$, a medida, sobre todo, que el conocimiento objetivo descubre nuevas realidades o nuevos modos de interpretar la realidad, pero también a partir de muchos otros procesos simbólicos, culturales y psicológicos, entre los que no debemos menospreciar la influencia del arte, la literatura y el teatro. Se producen así cruces y trasvases de una realidad a otra, obligándonos a una reestructuración cognitiva constante. La cultura occidental se ha destacado, precisamente, por la permanente ruptura de los límites de la realidad establecidos, especialmente a partir del Renacimiento y de modo más acelerado desde el siglo XVIII. El lugar e importancia, dentro de la realidad total, de la religión, el arte, la ciencia y la literatura han ido cambiando, en consecuencia, a lo largo de estos siglos, pues cada nuevo descubrimiento o avance cognitivo ha obligado a una reestructuración de esa realidad total, con sus diversos niveles de realidad, en la que cualquier sociedad se fundamenta. Podríamos afirmar que toda sociedad necesita definir estos tres niveles de realidad señalados, y necesita además jerarquizarlos, pues es una condición básica de cualquier intercambio social el compartir un acuerdo mínimo sobre el carácter y los límites simbólicos de la realidad. Cada individuo, a su vez, asume de modo personal esos límites, pudiendo incluso establecer su propia jerarquía significativa. Así, para unos (platónicos y hegelianos incluidos), la realidad invisible o suprasensible que la religión supone y considera efectivamente existente, puede ocupar el lugar más importante por considerarla la fuente o el

${ }^{7}$ Los griegos primitivos trataban a sus dioses como una realidad transreal efectivamente existente, más real que la realidad real; incluso les asignaron un espacio geográfico real, el monte Olimpo. Del mismo modo, muchos cristianos consideran a la figura de Jesucristo más real y poderosa que cualquier persona de este mundo. Con el tiempo, los griegos acabaron considerando a sus dioses como realidades imaginarias y hoy les otorgamos una realidad meramente ficticia. El movimiento de las fronteras, sin embargo, como muy bien afirma Teodosio Fernández, no implica su desaparición: «Los avances científicos no terminan con los misterios, como el desarrollo de la teología no anuló lo insólito de los milagros, ni el psicoanálisis [...] ha puesto fin al horror de las pesadillas» (Fernández, 2001: 296). 
origen de todo lo real manifiesto o visible. Para un científico cuántico es tan importante lo conocido como lo que aún no conocemos acerca de la realidad del universo. Para un poeta, las intuiciones o experiencias de una realidad oculta o sentida pueden ser más importantes que las percepciones inmediatas. De acuerdo con la situación personal, los intereses particulares, la experiencia o los deseos insatisfechos, cada individuo selecciona de la realidad total aquello que de verdad le interesa o preocupa, dejando de lado fragmentos enteros o mundos completos a los que no tiene acceso por la razón o motivo que sea, desde la incapacidad al desinterés, del mismo modo que otro individuo puede centrar su atención y su curiosidad en campos de la realidad totalmente ajenos para los gustos y afanes de la mayoría. En definitiva, cada individuo, dentro de los límites que la sociedad y los grupos de pertenencia imponen, percibe y jerarquiza la realidad de estos tres mundos $(M R, M T R$ y $M I$ ) a su modo, porque lo más importante no es tanto el nivel de realidad que a cada mundo otorga cuanto la significación que a cada realidad concreta concede $^{8}$. Se establecen así intercambios y focalizaciones de interés que pueden variar a lo largo de la vida e incluso en función de los contextos en los que el individuo se encuentre. El hombre moderno ha comprendido que la realidad es compleja, que no siempre lo real de verdad coincide con lo significativo o importante, que el placer y la felicidad no consisten sólo en conformarse o limitar los actos y expectativas al mundo perceptible o el sentido común, que gran parte de los impulsos vitales más profundos no pueden ser satisfechos con la adecuación a esa sola realidad, etc. También está prevenido, por otro lado, contra la superstición o el engaño, contra el delirio o la pérdida del sentido de la realidad efectiva. La ciencia, además, ha vuelto cada día más evanescente el sentido de la verdad como certeza absoluta, lo que, por un lado, le libera de los estrechos límites de la razón y el sentido común (del empirismo y el realismo ingenuo de los sentidos y las evidencias inmediatas), pero, por otro, le sume en la incertidumbre y el miedo a que el

\footnotetext{
${ }^{8}$ Se podrían clasificar a los individuos, los grupos y las culturas en función del modo particular como integran, jerarquizan y resuelven las contradicciones de estas tres realidades o mundos. Los realistas ingenuos y los realistas dogmáticos se colocarían en el extremo de quienes consideran al MR como lo único existente e importante; en el otro extremo estarían los realistas escépticos. Entre quienes creen que el $M T R$ es lo único verdaderamente existente e importante encontraríamos a los idealistas platónicos, los fundamentalistas religiosos o creyentes dogmáticos, a un lado, y al otro, algunos científicos, artistas y buscadores espirituales. Entre los que otorgan la mayor importancia y realidad al $M I$ estarían, por una parte, todos los enfermos más o menos psicóticos o delirantes, y los absolutistas subjetivos, creadores o soñadores, por otra. Y luego todo tipo de clasificaciones intermedias. Lo interesante es descubrir que todos nos vemos obligados a valorar y jerarquizar esos tres tipos de realidad, y que no siempre la solución es coherente. Se pueden dar casos de realistas dogmáticos que creen en las cosas más fantasiosas imaginables, o místicos espiritualistas obsesionados por la adquisición de bienes materiales.
} 
mundo se vuelva inconsistente o caótico. El teatro, ya lo hemos dicho, nace para romper las rígidas fronteras con las que el orden social trata de configurar la realidad total (para hacer menos inquietantes las vacilaciones sobre el carácter de la realidad) o, por el contrario, para confirmar un orden de relación y jerarquía entre los tres mundos señalados.

Estos tres mundos están siempre en permanente interacción. Podemos imaginar cinco modos de relación:

1. Separación, distinción, establecimiento jerárquico de fronteras: es el modo preferido por la razón y el sentido común, ya que asegura el orden y la estabilidad simbólica de la realidad sobre la evidencia inmediata.

2. Contacto, acercamiento, permeabilidad o difusión de fronteras: es el modo preferido por las formas subjetivas de pensamiento. El sujeto establece zonas de transición y transferencia entre los tres niveles de realidad, respondiendo a una necesidad de vivencia, de experimentar la realidad total y sentirse unido a todo lo existente.

3. Intersección, establecimiento de zonas y aspectos comunes, analogías, asociaciones: se mantiene la distinción pero se enfatiza lo idéntico o semejante. Es el modo de todas las creencias no dogmáticas, en las que se acepta la realidad empírica, pero se le otorga a las otras realidades un estatus simbólico semejante.

4. Fusión, indistinción, mezcla o confusión: aquí podemos encontrar gran variedad de formas o modos de relación entre estos tres mundos, desde la locura, en la que se confunden los tres niveles de realidad, otorgando a la imaginación una validez indiscriminada, hasta la religión o la magia, en la que el orden oculto de la realidad invisible es el principio rector y sostén de todo cuanto existe, o los sueños, en los que tampoco se puede establecer una separación nítida entre fantasía y realidad.

5. Intercambio, trasvase, conmutación: es el modo del arte, la literatura y el teatro, en el que una realidad del tipo $1(R O)$ se puede volver de tipo $2(R T R)$ o de tipo $3(R I)$ y al revés, con todas las combinaciones posibles.

Como puede deducirse, la $R T$ o Realidad Total, con sus distintos niveles, orden y jerarquía simbólica, no es algo dado, hecho, acabado, sino que se crea, 
se construye y sostiene permanentemente a través, fundamentalmente, del lenguaje y las instituciones sociales. Cada cultura, a través del lenguaje y las instituciones, asegura sobre todo una distinción básica: lo que es verdaderamente real o «real de verdad» de lo que no lo es. Dado que no resulta fácil discriminar o confirmar el grado o nivel de realidad de gran parte de los hechos y realidades de este mundo (desde los pensamientos e intenciones de los demás, hasta el fundamento o realidad última de la materia y la energía), dada la dificultad de establecer un criterio objetivo y definitivo de qué entendemos por realidad, en suma, el establecimiento y mantenimiento de un orden simbólico y social común requiere la existencia de aparatos o medios específicos para asegurar un acuerdo o consenso básico sobre de los límites de la realidad. En verdad, desde que nacemos, y empezando por la familia, la sociedad mantiene una «presión» sobre el individuo para que aprenda a percibir, distinguir y otorgar realidad al mundo de un modo semejante a como todos los miembros de una misma cultura están necesitados y obligados a hacerlo. Existe una gran variedad de mecanismos e instituciones que sirve para configurar y mantener ese orden simbólico común: escuela, leyes, política, religión, medios de comunicación, etc. (lo que el estructuralismo marxista llamó «aparatos ideológicos»), pero también el arte, la literatura y el teatro. En este sentido, el teatro puede cumplir una función de resistencia y denuncia ante cualquier imposición de un orden simbólico que, mediante poderosos aparatos de coerción (como la televisión o la propaganda) construya una realidad «falsa», interesada, mediante la manipulación de la propia realidad social y humana ${ }^{9}$.

$\mathrm{Si}$ aplicamos al estudio del teatro el esquema conceptual propuesto mediante este diagrama, el de una pluralidad de realidades y mundos, podemos enunciar una serie de hipótesis o proposiciones:

\footnotetext{
9 Hoy asistimos a fenómenos preocupantes relacionados con los nuevos mecanismos de producción y reproducción de la realidad social, especialmente a través de la televisión. La imagen televisiva tiene un poderoso «efecto de realidad», ya que parte del supuesto de que la cámara no inventa, sino que recoge lo que «ve». La TV se convierte así en un aparato ideológico mucho más eficaz que cualquier otro del pasado, ya que no es sólo un medio de producción y reproducción ideológica, sino, y sobre todo, un aparato de producción y control de la realidad misma. Bajo apariencia de realismo (mostrar la realidad tal cual es), lo que en verdad hace es construir ideológicamente, y a la vez, la propia realidad y la representación mental de esa realidad. La imagen televisiva no es una copia de la realidad, ya que ella misma es una construcción física y mental —enfoque, encuadre, fragmentación, montaje, contextualización e interpretación verbal con la que siempre se acompaña-. Un deseo de control totalitario subyace a esa manipulación y construcción de imágenes televisivas que recorren en segundos el planeta para conformar una visión del mundo adecuada a los intereses de una minoría dominante. El mecanismo es muy sutil, porque cuanto más se muestra - y del modo más crudo y directo_-, más se oculta y tergiversa la realidad. La conciencia crítica se muestra impotente por lo desproporcionado de sus medios ante el poderoso influjo, directo y en gran parte inconsciente, de la imagen ideologizada, que trata de invadir hasta el último rincón físico y mental donde trate de encontrar reposo y privacidad cualquier ser humano.
} 
1. El teatro es una realidad real: el mundo escénico se nos presenta como una realidad espacio-temporal directamente perceptible.

2. El teatro es una actividad real: la práctica escénica se lleva a cabo por personas del mundo real.

3. El teatro es también una realidad imaginaria ficticia: la realidad escénica y los seres que en ella actúan son la materialización o concreción de un mundo y unos seres imaginarios y ficticios.

4. El teatro se construye con signos verbales y no verbales reales directamente perceptibles: sonidos, enunciados, gestos, colores, luces, objetos, volúmenes, ruidos, movimientos.

5. Todo signo teatral tiene un referente ficticio que puede ser, a su vez, real, transreal o imaginario.

6. El espectador es un receptor de realidades perceptibles que son, a la vez, ficticias. Para construir los referentes ficticios de los signos teatrales reales tiene que referirlos a un mundo real, un mundo transreal o un mundo imaginario, pero esto no cambia el carácter esencialmente ficticio de los signos y referentes de la representación teatral.

7. El teatro puede construir una realidad ficticia realista, una realidad ficticia fantástica, o una mezcla de ambas; es decir, tanto realidades y mundos posibles como imposibles (con relación al mundo real). Sean realistas o fantásticos, posibles o imposibles, siempre serán realidades y mundos de naturaleza ficticia con apariencia de realidad real.

8. El carácter necesariamente real y perceptible del teatro impone limitaciones físicas y temporales a la imaginación ficticia. Al ser además, una actividad realizada por seres humanos, se produce una inmediata traslación de la ficción al mundo real. La realidad real y no ficticia siempre está presente en el teatro como referente inmediato o directamente perceptible (el espacio arquitectónico real, el cuerpo de los actores, las acciones físicas, los signos escénicos), referente que tiene que ser borrado para construir sobre él o con él, el referente ficticio. El referente ficticio, a su vez, se construye por semejanza o por oposición a los referentes del mundo real ${ }^{10}$, lo que

10 «Desde luego, cada cual puede tener la opinión que considere más oportuna sobre la realidad y sobre sus relaciones con la literatura. Lo que nadie puede no advertir, y eso resulta decisivo, es que la referencia de lo natural, de lo razonable o verosímil, continúa posibilitando la percepción de las diferencias» (T. Fernández, 2001: 292). 
implica una traslación simultánea de la ficción al mundo real por parte del espectador.

9. Los efectos (estímulos, emociones y pensamientos) que el teatro produce en el espectador son realidades no perceptibles e imaginarias de naturaleza subjetiva. La manifestación real de estos efectos, sin embargo, sí puede ser percibida, analizada y valorada objetivamente.

10. El teatro se construye imaginariamente mediante el lenguaje verbal. El lenguaje en el teatro es una realidad real (un texto escrito) que puede dar lugar a otra realidad real (la representación en la que se incluye el texto hablado). El texto teatral escrito tiene, por tanto, un referente real que es la representación. Pero, además, el lenguaje escrito en forma dialogada, tiene sus propios referentes semánticos concretos que son los mismos que los del lenguaje ordinario. Para que esos referentes reales (del mundo real, transreal o imaginario) puedan transformarse en referentes ficticios, tienen que adquirir un sentido contextual coherente con el mundo general de la representación ficticia.

11. La distancia entre el contenido semántico real de los signos verbales teatrales (significado) y su nuevo contenido semántico contextual y ficticio (sentido) puede ser mayor o menor, según se trate de construir o inventar un mundo imaginario ficticio realista o un mundo fantástico, pero siempre será necesaria una traslación, transposición y comparación sustitutoria entre los referentes reales y los referentes ficticios.

12. La paradoja esencial del teatro consiste en crear una realidad que es real real sólo con la condición de que deje al mismo tiempo de serlo para convertirse en una realidad imaginaria, inventada y ficticia que, a su vez, ha de hacerse directamente perceptible. El teatro participa, por lo mismo, de dos niveles de realidad antagónicos: la realidad real y la realidad imaginaria, la realidad y la irrealidad. Esta naturaleza dual le permite, de modo privilegiado, trasladar la realidad a la ficción y la ficción a la realidad o, igualmente, la transrealidad a la ficción, y la ficción a la transrealidad.

13. El teatro, por todo ello, es necesariamente invención, creación de algo desconocido, una realidad que no existe como tal en ninguno de los tres mundos señalados, aunque participa de todos ellos. No puede ser, por lo mismo, una mera copia del mundo real, por mucho que lo parezca. Lo que se conoce no puede ser inventado. El realismo, en 
este sentido, es imposible en el teatro. Cualquier traslación o copia de la realidad necesita transformarse para inscribirse en una realidad ficticia e inventada. Pero, y al mismo tiempo, el teatro es mímesis, simulación o representación de una actividad humana real, por lo que, y en este sentido, ha de ser necesariamente «realista» o mimética. De nuevo, el oxímoron, la paradoja, la contradicción lógica. Interacción de mundos, no duplicación. A la realidad hay que añadirle y quitarle «cosas» para representarla. Mediante la simulación podemos pasar de un nivel de realidad a otro, establecer conexiones, trasvases, reequilibrios, sin caer ni en el ilusionismo ni en la resignación ante una realidad plana y rígida que anula el deseo. La realidad no es inmutable, podemos crearla y modificarla; podemos volverla, a través de la ficción, más interesante y significativa. Incluso, mediante el teatro, la realidad puede volvérsenos más extraña que la ficción, pues, como observa E.Bentley, «la verdad es más extraña que la ficción, pues ésta posee una coherencia que a aquélla le falta» (1982: 47).

El teatro crea un espacio intermedio para que lo ficticio deseado pueda hacerse real y lo real agobiante volverse ficción. Queremos hacer realidad los sueños y deseos, al mismo tiempo que necesitamos hacer menos real la realidad real, tomárnosla menos en serio. Todos vivimos en tres mundos a la vez, el $M R$, el $M T R$ y el $M I$. Llegar a un buen acuerdo entre estas tres instancias en las que nuestro ser real se hace presente es una necesidad vital, no mera recomendación psicoterapéutica. En verdad, nos va la vida en ello. Por eso necesitamos probar, ensayar, experimentar con la realidad y la ficción. Por eso nos interesa tanto la vida de los otros, para saber a qué atenernos, qué hacer ante la complejidad y la pluralidad de realidades que nos rodea y llama nuestra curiosidad y atención. No quisiéramos perdernos nada. Necesitamos poner orden, tener certeza, hacer consistente el mundo en que vivimos; pero también no limitarnos, experimentar y ampliar las fronteras de ese mundo, para lo cual hemos de aceptar la incertidumbre, probar con el «por si acaso», actuar «como si». Realidad e irrealidad, realismo e irrealismo. En verdad, de lo que huimos es de la muerte: no queremos perdernos o desaparecer en mundos ilusorios e irreales, pero tampoco quedar atrapados y perecer en las ruinas o escombros de un mundo ordinario y banal. Nuestro deseo más profundo es un deseo de permanencia, de esencialidad y plenitud. Un deseo de realidad completa. El teatro, en su sentido más real y profundo, crea modelos y experiencias en las que ese deseo pueda cumplirse de algún modo. Desfigura la realidad para transfigurarla o transubstanciarla y que así, en esa realidad total redescubierta, pueda tener acogida o reposo nuestro ser completo. 
Para lograr tan difícil experiencia el teatro crea, por su parte, distintos niveles de realidad:

1. La realidad real del espectador (está presente, mira, observa, reacciona, acepta la convención básica): R1.

2. La realidad escénica o realidad real del actor (actúa, interpreta): R2.

3. La realidad escenificada, real y ficticia, de los personajes (actúan y hablan): R3.

4. Realidad subjetiva e imaginaria —objetivada y manifiesta - de los personajes (recuerdan, cuentan, desean, planean, sienten, sueñan): R4.

5. La realidad imaginaria y subjetiva del espectador (rellena, evoca, siente, infiere, interpreta, valora): R5.

Podríamos representar estas cinco realidades mediante un gráfico triangular o piramidal en el que se superpusieran siguiendo un modelo tectónico ${ }^{11}$ o de niveles:

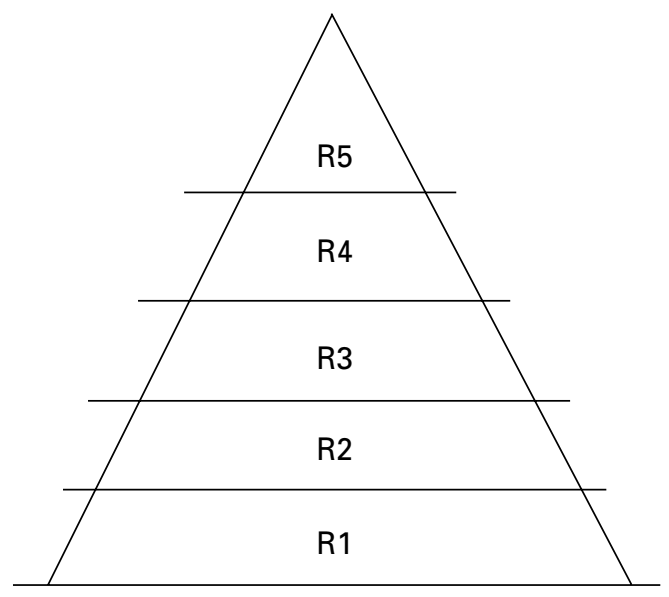

Esto significa que la R1 es el soporte o realidad básica inicial de la representación: toda la realidad representada se construye sobre el hecho necesario de una presencia real. La pirámide de la representación concluye, a su

${ }^{11}$ El gráfico puede representar un corte isocrónico e isotópico de cualquier momento de la representación. 
vez, en el espectador, en la realidad que él construye significativamente (R5) a partir de las otras tres realidades (R2, R3 y R4). La R2 del actor, por su parte, es el soporte o la realidad que hace posible la R3 y la R4 mediante las cuales se actualiza y realiza la ficción. Los personajes, por su lado, tienen dos niveles de realidad: R3 y R4. La R3 es la base o el soporte necesario para que la R4 pueda aparecer en escena. Los personajes ficticios primero han de adquirir una apariencia real (hablar y actuar como si fueran personas reales) para poder manifestar o mostrar su «interior». El interior (el mundo subjetivo e imaginativo de los personajes) sólo adquiere interés en el teatro si tiene que ver con su situación dramática, o sea, si ese interior se muestra como una acción integrada dentro de la acción dramática general. No tiene validez «por sí mismo». No puede construirse como realidad escénica si no es sobre la base de realidad que el personaje adquiere en su nivel anterior (R3). Estos cinco niveles de realidad están, por consiguiente, interrelacionados y son mutuamente dependientes. La representación es una totalidad integrada de estos cinco niveles de realidad. El resultado es algo artificial e inventado que no está ni existe, como tal, en ninguna parte del mundo, y sólo puede tener, por tanto, una existencia concreta, absoluta y fugaz. Sólo existe previamente como realidad imaginaria. Lo que se hace presente, lo que se re-presenta, es una realidad imaginaria, no una realidad real. Por lo mismo, todo realismo en el teatro es siempre de segundo orden. La representación representa una realidad imaginaria que, a su vez, es una ficción que representa una realidad real, una realidad fantástica o una mezcla de ambas. El problema, la dificultad, no reside en «copiar» la realidad, sino en transformar esa copia en ficción (mímesis). El problema, la dificultad, tampoco reside en inventar o imaginar una ficción, sino en hacer real esa ficción mediante el texto y la representación. En definitiva, el teatro no puede actuar directamente sobre la realidad, sino sobre las representaciones de la realidad ${ }^{12}$.

Todo realismo en el teatro, en consecuencia, es un realismo artificial: no sólo porque la representación es evidentemente algo preparado, ensayado y construido, sino porque la realidad a la que se refiere o representa es siempre una interpretación de la realidad, nunca una reproducción o copia objetiva. En este sentido, todo realismo escénico es una ficción realista. La diferencia entre ficción realista y ficción fantástica no es propiamente una distinción basada en la naturaleza ontológica del referente, sino en la intención del autor del texto teatral o de los autores de la representación. En el caso del realismo,

12 Como dice H. Müller (1990: 22) «la realidad en realidad no me interesa si no está elaborada. Me interesa la elaboración de la realidad y no la realidad misma». 
el autor (o autores) se sitúa como observador e imitador objetivo, aunque no pueda serlo más que intencionalmente. En el caso de la ficción no realista, se prescinde de esta intención y se deja libre la creatividad. En el primer supuesto, la ficción e interpretación de la realidad construida artificialmente habrá de acomodarse a lo que el receptor entiende por realidad, o sea, sostener siempre la ilusión de realidad referencial objetiva o lo más cercana a la realidad extraescénica que se quiere imitar o representar. En el otro, la ficción no realista, igualmente construida de modo artificial, habrá de respetar y sostener la ilusión de referencialidad verosímil inventada imaginariamente sin tener en cuenta ninguna realidad extraescénica. En ambos casos, el problema que a todo autor se le plantea es el de construir una ficción verosímil aceptable por parte del espectador. En el realismo, la verosimilitud ha de acercarse a la verdad o realidad real; en el antirrealismo, la verosimilitud se sostiene mediante la coherencia interna de la realidad inventada. Ambas estrategias están amenazadas por un exceso del ilusionismo («hipnótico», le llama B. Brecht): ilusionismo realista o ilusionismo fantástico ${ }^{13}$. Ambos acaban tomando por real de verdad (sintiéndolo) lo que no es más que ficción: los espectadores (o los actores) se olvidan de que están en el teatro. Lo difícil, y esencial, tanto para el realismo como para el antirrealismo, es mantener ese carácter dual y paradójico del que hemos hablado tanto: realidad y ficción. El teatro se nos presenta como el medio más original y eficaz de unir, interconectar y enfrentar el mundo de la realidad $(M R)$ con los otros dos mundos (MI y $M T R)$. El teatro es un arte de intermediación: interviene para resolver los «conflictos entre mundos».

El atractivo del realismo radica en producir dos efectos simultáneos: el reconocimiento y la extrañeza o alejamiento. El atractivo del antirrealismo y del «realismo fantástico» se asienta, igualmente, en suscitar dos reacciones complementarias: descubrimiento y sorpresa o acercamiento. Existe un placer en el reconocimiento de lo conocido, pero también en el descubrimiento de lo desconocido. Igualmente necesitamos que lo familiar se vuelva de vez en cuando extraño o irreconocible para sentirlo de nuevo como atractivo; lo fantástico e inalcanzable, a su vez, necesitamos volverlo real y sorprendernos con su presencia y cercanía. Si lo familiar, habitual o conocido se vuelve de-

\footnotetext{
13 Se podría decir que tanto la mímesis realista como la fantástica (representación de una realidad imaginaria) necesitan de la imaginación y la fantasía, dos conceptos estrechamente unidos y complementarios: La fantasía es más exterior que la imaginación. La fantasía va hacia fuera, la imaginación hacia adentro. Una produce espectáculo, sorpresa; otra, extrañeza y conmoción. La fantasía provoca admiración; la imaginación identificación, proyección, transferencia. La fantasía, impacto; la imaginación, deseo, implicación.
} 
masiado extraño y lejano (incontrolado) nos inquieta y asusta; si lo irreal e imaginario se acerca demasiado o nos arrebata, también nos produce temor e inseguridad. Necesitamos la realidad real para asentarnos en este mundo y controlar nuestra vida, pero también necesitamos liberarnos de los límites de esa realidad para ampliar el mundo, o transformarlo, y así vivir nuevas o más intensas experiencias. En el teatro comprobamos que la realidad ordinaria y conocida puede volverse extraña mediante un ligero cambio o una nueva contextualización. Igualmente, el teatro hace visibles y reales las más inusitadas fantasías o deseos. Extrañeza ante lo conocido, sorpresa ante lo desconocido o deseado. Lo que en realidad se transforma es nuestra mirada, nuestro modo de percibir e interpretar la realidad y, con ello, nuestro propio modo de percibirnos y comprendernos, y de percibir y comprender al otro. Lo que comprendemos es que, para que el mundo cambie, debemos verlo y mirarlo con otros ojos, oír con otros oídos, escuchar e interpretar la realidad con otra actitud y otra mente. Distanciar la realidad, acercar la irrealidad. Convertir lo ordinario en extraordinario, y al revés. Se puede lograr esta doble transformación mediante dos procedimientos opuestos: el «embellecimiento» o la «deformación». La belleza es la creación de una realidad ideal basada en los principios de armonía, simetría, equilibrio, ritmo, integración, totalidad; lo grotesco o deforme es la creación de una realidad en la que lo asimétrico, el desequilibrio, la fragmentación, la desproporción y la «incompletitud» se manifiestan. Mediante ambos procedimientos, y con frecuencia mezclándolos, se logra atraer la atención del espectador y hacer que lo insignificante se vuelva significativo, y lo demasiado significativo, insignificante. El mundo se puede volver al revés: lo serio, broma, y la broma, algo serio. A la realidad le sobra y le falta algo a la vez. Ese plus y ese menos lo podemos descubrir al contemplar la escena, vivirla e interpretarla. Ni el realismo puede reproducir la realidad, ni la fantasía vivir en las nubes.

Pero no queremos confundir la realidad con la ficción, sino enfrentarlas. Si no pudiéramos distinguir y saber que una cosa es la realidad y otra la fantasía y la ficción, el mundo entero se tambalearía. Podemos dudar, sentir un instante de miedo o pavor al perder el sentido de la realidad, pero para volver enseguida a recuperarlo. El control de nuestra mente nos asegura el control del mundo que nos rodea. Hay un placer en pasar por esa experiencia de incertidumbre, porque es como aprender a salir de la realidad y a volver a ella. Cuanto mayor es el susto mayor es el alivio y la vuelta a la normalidad. El experimentar esa pérdida de realidad en un contexto controlado (el teatro o el cine) nos ayuda a un mejor control de nuestra propia irrealidad, ese flujo de conciencia sobre el que sólo podemos establecer un dominio superficial o 
consciente, mientras que la mayor parte de su actividad permanece inconsciente y latente. El dar rienda suelta, de forma transitoria y controlada, a ese mundo inconsciente en el que se borran las fronteras entre lo real y lo irreal, es un medio eficaz para reforzar nuestro control y seguridad, dando salida, al mismo tiempo, a nuestros miedos más profundos. La ficción realista y la ficción fantástica cumplen, desde esta perspectiva, la misma función, ya que responden a las mismas necesidades humanas.

El realismo conjura los miedos del mundo exterior o embellece y transforma el mundo exterior. Ya sea para conjurar lo siniestro oculto en la realidad exterior (el mundo y los otros), o para revelar la «belleza» presente en esa misma realidad exterior, el realismo opera transformando la realidad. La fantasía conjura los miedos interiores, les da vida y hace reales para distanciarlos o «sacarlos fuera»: libera la tensión interior, revitaliza el deseo y construye estímulos imaginarios para sostener el impulso.

Hoy se está produciendo un fenómeno nuevo que obliga a reconstruir o crear nuevas fronteras entre realidad y ficción, pero no a destruirlas. Nos referimos a la realidad virtual. Entre las imágenes realmente percibidas del mundo exterior, y las imágenes interiormente construidas por la fantasía o el deseo, se interpone hoy un mundo nuevo de imágenes que ni son exteriores ni interiores, sino que son ambas cosas a la vez. La imagen virtual está entre la realidad del mundo exterior y la realidad del mundo interior. Es imagen real, exterior, percibida a través de los sentidos, pero es también imagen interior, construida mentalmente. Su valor como sustituto de la realidad real depende de nosotros, del valor y el contenido de realidad que le otorguemos. Sus efectos dependerán de la capacidad que tengamos para «entregarnos», para relacionarnos con ella como si fuera realidad de verdad. Al otorgar realismo a las imágenes virtuales estamos borrando las fronteras entre realidad y ficción. Pero, y este es nuestro modo de integrar esta nueva experiencia, esta confusión entre realidad y ficción sólo dura el tiempo en que nos entregamos a vivir la realidad virtual como si fuera real: mientras estamos sumergidos en ella podemos llegar a olvidar que no es del todo real, que es una imagen artificial, pero, en cuanto salimos del juego o la experiencia, volvemos a nuestra realidad efectiva. Hemos ido aprendiendo a reaccionar así, a entrar y salir de la realidad de las imágenes artificiales a la realidad del mundo, desde que empezó el cine, y más aún desde que la televisión se ha instalado en medio de nuestras casas (casi siempre, además, en un lugar central). Nuestros antepasados, si contemplaran de pronto esas imágenes fílmicas o virtuales, después de superar la sorpresa o satisfacer su curiosidad, reaccionarían de dos formas extremas: o tomando las imágenes por lo que 
son, puras imágenes carentes de interés real, con dimensiones ridículas, con un orden disparatado, etc., o, por el contrario, como seres o formas reales ante las que sentirían miedo o pavor. Comprobaríamos de este modo que las imágenes no son nada sin su interpretación. Se dice que una imagen vale más que mil palabras. Esto a veces ha llevado a algunos a suprimir las palabras del teatro. Es cierto que la información icónica es mucho más completa, desde el punto de vista de los sentidos, que una palabra: color, forma, luz, movimiento, profundidad, velocidad, composición, enfoque, dimensión, capacidad de transformación, de mímesis y de evocación. La imagen dinámica contiene una gran cantidad de signos y connotaciones que captan de forma casi inmediata la atención del espectador, al mismo tiempo que reducen su capacidad discursiva y valorativa, aunque sólo sea porque los recursos atencionales son limitados. Pero olvidamos que todas esas imágenes no tendrían ningún sentido ni interés si no fueran reconstruidas y recolocadas mentalmente en un contexto significativo desde el mismo momento en que son percibidas. A crear ese contexto colabora de modo muy eficaz la música y los sonidos que casi siempre acompañan a las imágenes visuales y virtuales, pero sobre todo la palabra, que no sólo sirve para crear ese contexto, sino para interpretar y valorar las imágenes que, por sí solas, carecen de valor y significación. Supongamos que vemos en pantalla a un hombre que saca del bolsillo una pistola y dispara contra otro hombre que cae al suelo. Estas imágenes pueden referirse a un asesinato real o a uno ficticio; pueden, incluso, hacerse pasar por reales para confundir a la policía o a alguna otra persona; pueden referirse a un asesino abatido por a un agente no uniformado quien, al disparar contra la víctima, salva con ello la vida de otras personas; o puede que el policía sea el que ha caído al suelo y el asesino el que dispara; o que todo haya sido fruto de una confusión y un tremendo error, etc. Su efecto sobre el espectador será también muy distinto si se acompañan las imágenes de una música u otra, dentro de una programa televisivo u otro, etc. En fin, como podemos comprobar, las imágenes no están, en principio, reñidas con las palabras, sino que las necesitan para adquirir interés y valor, para poder ser interpretadas. Vivimos hoy, como siempre, en una sociedad de «imágenes y palabras». El problema nuevo que hoy nos planteamos es el de no sucumbir a la fascinación y la anulación cognitiva que las imágenes producen al exigir una atención casi total para ser entendidas, vividas e interpretadas. El conseguir que, a pesar de todo, las palabras puedan ejercer una labor crítica sobre los efectos de esas imágenes y actuar libremente, desarrollando la propia capacidad de análisis, comprensión e interpretación de la realidad, éste es el reto que plantea al hombre actual la invasión casi totalitaria de las imágenes; imágenes, repetimos, que nunca se nos presentan solas, sino interpretadas e 
ideologizadas. Las imágenes más tóxicas y desvitalizadoras son, sin duda, las imágenes televisivas, que se presentan con un estatus de objetividad realista. Desenmascarar la mentira de este doble de la realidad, descubriendo todos los trucos y manipulaciones mediante las cuales las imágenes, desde su propio origen, se convierten en «ideológicas» (portadoras de una interpretación de la realidad interesada) es también una de las posibles funciones del teatro.

A todo esto, al modo particular en que el arte construye la realidad ficticia, ya sea realista o fantástica, Darío Villanueva lo llama acertadamente «realismo intencional», o sea, un efecto de realidad que es el «resultado de la cooperación activa del lector» (1992: 122) —entiéndase también del espectador-.

Para comprender lo que percibimos tenemos que darle una intencionali$d a d$, construir la realidad como portadora de una intención. La intención da sentido y pone orden a lo percibido; sin ella no entenderíamos nada de lo que percibimos. La interpretación va unida a la percepción, guía la percepción y descarta lo que no se acomoda a la intención. La cointencionalidad o intencionalidad compartida es lo que produce la cognición social. Por eso todo «realismo es siempre producto del lector». A partir de este hecho D.Villanueva estable lo que él mismo llama una «audaz conjetura»:

Que el teatro es la forma paradójicamente más anti-realista, porque la presencia física del espectador y su contacto con los actores que encarnan a los personajes, más todos los otros sistemas de signos puestos al servicio de la ilusión referencial, producen el efecto contradictorio, de artificiosidad y de verdadero irrealismo, a lo que cabría añadir que la epojé o pacto de ficcionalidad, a diferencia de lo que ocurre en el proceso interno de la lectura, cesa de operar en el momento en que esa ceremonia pública que es la representación termina (1992: 183).

Así ocurre, en efecto, y de modo paradójico y «realista».

\section{REFERENCIAS BIBLIOGRÁFICAS}

ANCET, J. (1999). «La voz y el pasaje». Cuadernos Hispanoamericanos 589-590, julio-agosto, 89-93.

Bentley, E. (1982). La vida del drama. Barcelona: Paidós.

BERgSOn, H. (1986). La risa. Madrid: Espasa-Calpe. 
FERNÁNDEZ, T. (2001). «Lo real maravilloso de América y la literatura fantástica». En Teorías de lo fantástico, D. Roas (ed.), 283-297. Madrid: Arco/Libros.

Gutiérrez Carbajo, F. (2001). Teatro contemporáneo: Alfonso Vallejo. Madrid: UNED.

LyOTARD, J. F. (1989). La Fenomenología. Barcelona: Paidós.

Morales Astola, R. (1992). «Teatro y realidad: textos espectaculares». En Investigaciones Semióticas IV, vol. II, 423-427. Madrid: Visor Libros.

MülLER, H (1990). Teatro escogido, ed. de J. Riechmann. Madrid: Primer Acto.

Paz GaGo, J. M. a (1992). «Realismo, realidad y ficción realista». En Investigaciones Semióticas IV, vol. II, 707-711. Madrid: Visor Libros.

PÉREZ BOWIE, J. A. (2004). Realismo teatral y realismo cinematográfico: las claves del debate (1910-1936). Madrid: Biblioteca Nueva.

Trancón, S. (2000). «Percepción, teatro y mundo mágico». Acotaciones, enero-junio, 42-61 (Madrid: RESAD/Fundamentos).

Villanueva, D. (1992). Teorías del realismo literario. Madrid: Instituto de España / Espasa Calpe.

NOTA: Para más datos puede consultarse mi tesis de doctorado, defendida en la UNED, en la página electrónica del Centro de Investigación, dirigido por el profesor José Romera Castillo, http://centro-investi gacion-SELITEN@T. 